\title{
PENGELOLAAN SUPERVISI AKADEMIK DI SMPN 1 TODANAN BLORA
}

\author{
Wiwin Wahyuningsih dan Sofyan Anif \\ Magister Administrasi Pendidikan Sekolah Pascasarjana \\ Universitas Muhammadiyah Surakarta \\ misswi2n@gmail.com \\ sa163@ums.ac.id
}

\begin{abstract}
The aim of this study to describe the planning, implementation, feedback and followup of the academic supervision at Junior High School 1 Todanan Blora. This study includes qualitative research with ethnographic design. Research is located at Junior High School 1 Todanan Blora. The study begins from July 2015 to January 2016. The subjects of the research are principal, vice principal of curriculum, teachers of subjects. The technique of collecting data through observation, in-depth interviews, and documentation. The interview process uses first order understanding and second order understading. The validity of the data with simber triangulation of source, triangulation techniques, and triangulation of time. Data analysis technique uses flow method. The results of the study (1) The planning process of supervision contains making supervision schedule and assessment instruments of supervision conducted by the principal and vice principal of curriculum, (2) The implementation of academic supervision is carried out with the preparation of supporting supervision documents and continue with classroom observation by supervisors, (3) Feedback process of supervision is done by evaluating the academic supervision, as well as providing a solution to solve the problem experienced by teachers in teaching, (4) The follow-up of supervision is done by supervisor continuously and providing the opportunity for teachers to follow training activities to improve their capability of teaching.
\end{abstract}

Keywords: academic supervision , feedback, follow-up, implementation, planning

\begin{abstract}
ABSTRAK
Tujuan penelitian ini untuk mendeskripsikan perencanaan, pelaksanaan, umpan balik, dan tindak lanjut supervisi akademik di SMPN 1 Todanan Blora. Penelitian ini termasuk penelitian kualitatif dengan desain etnografi. Penelitian berlokasi di SMPN 1 Todanan Blora. Waktu penelitian bulan Juli 2015 sampai Januari 2016. Subyek penelitian Kepala Sekolah, wakasek kurikulum, guru mata pelajaran. Teknik pengumpulan data dengan observasi, wawancara mendalam, dan dokumentasi. Proses wawancara yang digunakan yaitu first order understanding dan second order understading. Keabsahan data dengan triangulasi sumber, triangulasi teknik, dan triangulasi waktu. Teknik analisi data menggunakan metode alur. Hasil penelitian
\end{abstract}


(1) Proses perencanaan supervisi berisi pembentukan jadwal supervisi dan instrumen penilaian supervisi yang dilakukan oleh kepala sekolah dan wakasek kurikulum, (2) Pelaksanaan supervisi akademik dilakukan dengan persiapan dokumen penunjang supervisi dan dilanjutkan dengan observasi kelas oleh supervisor, (3) Proses umpan balik supervisi dilakukan dengan evaluasi supervisi akademik, serta pemberian solusi untuk mengatasi kendala yang dialami guru dalam pembelajaran, (4) Tindak lanjut supervisi dilakukan dengan pengawas pada guru secara terus menerus, serta pemberian kesempatan kepada guru mengikuti kegiatan training untuk meningkatkan kemampuan dalam pembelajaran.

Kata Kunci: tindak lanjut, umpan balik, pelaksanaan, perencanaan, supervisi akademik

\section{PENDAHULUAN}

Pendidikan merupakan suatu proses inti dalam mencerdaskan kehidupan bangsa sehingga harus dilakukan secara profesional. Kemajuan suatu bangsa ditentukan oleh mutu sumber daya manusia (SDM), khususnya para penerus bangsa. Pendidikan digunakan untuk mewujudkan sumber daya manusia (SDM) yang berkualitas. Dengan demikian kemajuan suatu bangsa dipengaruhi oleh faktor pendidikan yang diperoleh penerus bangsa.

Kemajuan suatu bangsa hanya dapat dicapai melalui penataan pendidikan yang baik dan tenaga pendidik yang profesional. Ujung tombak pendidikan terletak pada pendidikan disekolah yang menjadi tanggung jawab guru . Pendidik (guru) yang diperlukan untuk mewujudkan kehidupan yang cerdas adalah pendidik yang mampu memberdayakan seluruh potensi dan kemampuan dirinya demi tercapainya tujuan pendidikan. "Pendidikan bermaksud membantu peserta didik untuk menumbuh kembangkan potensi-potensi kemanusiaannya." (Raharjo, 2014: 29).

Namun beberapa guru belum memberdayakan seluruh kemampuan yang dimilikinya dalam mengembangkan metode pengajaran selama proses pembelajaran berlangsung. Hal ini menyebabkan peserta didik belum mampu mencapai kompetensi individual yang diperlukan dalam kehidupan sehari-harinya. Menurut Tumruzi (2011: 1), peserta didik baru mampu mempelajari fakta, konsep, teori, prinsip, hukum, dan gagasan inovatif dalam ingatan mereka disebut menghapalkan. Peserta didik belum sampai pada tahap pemahaman, sehingga peserta didik belum mampu menerapkan ilmu yang mereka dapat secara efektif dalam pemecahan masalah sehari-hari.

Dalam Peraturan Menteri Pendidikan Nasional (PERMENDIKNAS) Nomor 16 Tahun 2007 tentang standar kualifikasi guru menyebutkan bahwa ada empat kompetensi minimal yang harus dimiliki seorang guru, yaitu: kompetensi kepribadian, pedagogik, profesional, dan sosial. Demi mencapai kompetensi minimal tersebut, berbagai upaya ditempuh baik dari pihak sekolah maupun pemerintah, baik secara individu maupun kelompok melalui berbagai kegiatan baik pelatihan maupun pembinaan. Namun upaya tersebut belum memperlihatkan hasil yang signifikan karena adanya kendala waktu, budaya dan pola pikir yang sulit diubah.

Untuk meningkatkan kualitas pendidikan di Indonesia maka hal diperhatikan adalah 
proses pembelajaran. Proses pembelajaran yang efektif dan efisien merupakan kunci untuk mendapatkan hasil pembelajaran yang berkualitas dan maksimal. Oleh sebab itu diperlukan pengawasan (supervisi) dalam proses pembelajaran. Hoy and Forsyth (1986) dalam Muslim (2009:38) menyatakan supervisi adalah serangkaian kegiatan yang disusun untuk meningkatkan dan memperbaiki proses pembelajaran. Supervisi juga diartikan sebagai berikut "serangkaian usaha pemberian bantuan kepada guru dalam bentuk layanan profesional yang diberikan oleh supervisor (kepala sekolah, pemilik sekolah, dan pembina lainnya) guna meningkatkan mutu proses dan hasil belajar-mengajar".

Arikunto (2004) dalam Winaryanti (2014: 4) mengungkapkan Supervisi Akademik merupakan salah satu jenis supervisi yang dilaksanakan di sekolah yang menitik beratkan pada masalah dalam kegiatan pembelajaran. Pernyataan tersebut menjelaskan bahwa supervisi akademik berfokus pada perbaikan proses pembelajaran guna meningkatkan mutu pendidikan dan hasil belajar siswa. Proses pembelajaran dapat berlangsung secara efektif jika guru mampu mengoptimalkan potensi yang dimilikinya dalam mengembangkan bahan ajar dan metode pembelajaran. Olivia (1984:16) menjelaskan bahwa supervisi memiliki tujuan yaitu membantu guru dalam mengembangkan proses kegiatan pembelajaran, membantun guru dalam menafsirkan kan mengembangkan kurikulum serta perangkat mengajar dalam proses belajar mengajar, dan membantu guru mengembangkan kemampuan yang telah dimilki untuk meningkatkan kualitas guru tersebut.

Kenyataan yang terjadi beberapa guru masih menggunakan metode lama seperti ceramah, guru kurang kreatif dalam mengembangkan materi pembelajaran dan penyusunan perangkat pembelajaran yang cenderung hanya copy paste. Gaya pembelajaran yang masih konvensional ini cenderung menimbulkan rasa jenuh bagi siswa yang mengakibatkan tidak maksimalnya hasil belajar yang dicapai. Berdasarakan kenyataan yang terjadi, untuk meningkatkan mutu pendidikan seorang kepala sekolah perlu melakukan Supervisi Akademik pada setiap guru untuk membantu guru lebih mengembangkan potensinya dalam mengelola proses pembelajaran. Inti dari kompetensi Supervisi Akademik adalah membina guru dalam meningkatkan mutu proses pembelajaran (Prasojo dan Sudiyono, 2011: 83). Haryanto (2010) menyatakan pengolalaan supervisi adalah suatu proses pendayagunaan sumber daya yang tersedia dengan tujuan membina guru sehingga mampu melakukan proses pembelajaran dengan baik.

Tujuan penelitian ini ada 4 yaitu: (1) Mendeskripsikan perencanaan supervisi akademik di SMPN 1 Todanan Blora; (2) Mendeskripsikan pelaksanaan supervisi akademik di SMPN 1 Todanan Blora; (3) Mendeskripsikan umpan balik supervisi akademik di SMPN 1 Todanan Blora; (4) Mendeskripsikan tindak lanjut supervisi akademik di SMPN 1 Todanan Blora.

\section{METODE}

Penelitian ini termasuk dalam katagori penelitian kualitatif. Menurut Sutama (2012: 32) penelitian kualitatif memilki tujuan untuk memahami fenomena sosial dari prespectif participant (membuat teori). Penelitian kualitatif adalah jenis penelitian dimana peneliti berperan sebagai instrumen (alat) utama dalam pengumpulan data. Desain penelitian ini adalah penelitian etnografi yang mendeskripsikan suatu fenomena namun tidak sampai pada tahap pemaknaan. Sukmadinata (2009:62) menyatakan studi etnografi (etnographic studies) 
merupakan ilmu yang mendeskripsikan dan menginterpretasikan budaya, kelompok sosial atau sistem. Studi etnografi berpusat pada pola-pola kegiatan, bahasa, kepercayaan, ritual dan cara-cara hidup.

Penelitian ini dilakukan di SMPN 1 Todanan Blora. Penenlitian dilakukan selama 7 bulan dimulai pada Juli 2015 sampai Januari 2016. Subyek penelitian yaitu Kepala sekolah, Wakasek kurikulum, Guru mata pelajaran. Data dikumpulkan dengan menggunakan tiga teknik pengumpulan data yaitu observasi, wawancara, dan dokumentasi.

Teknik analisis data dalam penelitian ini menggunakan metode alur. Proses analisis data dilakukan secara terus menerus hingga mencapai titik jenuh dan dilaksanakan dengan cara berurutan yaitu: (1) Pengumpulan data; (2) Reduksi data; (3) Penyajian data; dan (4) Penarikan kesimpulan atau verifikasi. Keabsahan data menggunakan tenik triangulasi data. Triangulasi yang digunakan peneliti meliputi triangulasi sumber, triangulasi teknik, dan triangulasi waktu.

\section{HASIL DAN PEMBAHASAN}

\section{Perencanaan Supervisi Akadaemik di SMPN 1 Todanan Blora}

Perencanaan merupakan tahap yang sangat penting dalam suatu kegiatan termasuk supervisi akademik di sekolah. Tahap perencanaan merupakan tahap paling awal dari suatu kegiatan yang membahas tentang apa yang akan dilakukan, siapa pihak yang melakukan, kapan waktu pelaksanaan, dimana tempat berlangsungnya kegiatan, dan bagaimana melakukkannya serta target yang harus dicapai dari kegiatan tersebut.

Supervisi akademik di SMPN 1 Todanan Blora memerlukan jadwal pelaksanaan yang akurat supaya dapat berjalan dengan efektif dan sesuai dengan urutannya. Jadwal disusun untuk memberikan panduan pada kepala sekolah dan guru mengenai waktu, tempat, dan siapa yang terlibat dalam supervisi penyusunan jadwal dilakukan oleh kepala sekolah dan wakasek kurikulum. Hal ini senada dengan penelitan yang dilakukan oleh Florence (2010) yang menyatakan bahwa supervisi dapat berjalan dengan baik dengan adanya perencanaan yang baik pula. Hal ini berarti pembentukan jadwal pelaksaan supervisi akademik memilki pengaruh besar terhadap jalannya supervisi tersebut.

Supervisi akademik di SMPN 1 Todanan Blora berjalan secara efektif dan efisien dengan adanya perencanaan yang baik dari masing-masing pihak yang terlibat yaitu kepala sekolah dan wakasek kurikulum. Perencanaan yang baik membantu supervisi akademik mencapai tujuan yang telah ditetapkan dan memeperoleh hasil yang maksimal. Hal ini sejalan dengan penelitian Carrie (2009) bahwa penentuan jenis supervisi yang akan diberikan pada guru dapat meningkatkan keefekitifan supervisi dan memberikan kenyamanan pada guru dalam menjalani supervisi. Hal tersebut menunjukkan bahwa perencanaan merupakan panduan dalam menjalankan kegiatan supervisi akademik disekolah. Perencanaan supervisi akademik penting karena menbantu supervisi akademik berjalan efektif dan tepat sasaran serta dapat meningkatkan mutu pendidikan di sekolah melalui peningkatan kinerja guru selaku ujung tombak pendidikan di sekolah.

Supervisi akademik di SMPN 1 Todanan Blora memerlukan dokumen-dokumen penunjang jalannya supervisi yang meliputi perangkat mengajar guru. Persiapan dokumen penunjang supervisi dilakukan dengan cara kooperatif atau bekerja sama. Komponen yang terlibat dalam 
persiapan dokumen supervisi meliputi pihak yang terlibat dalam kegiatan supervisi akademik yaitu kepala sekolah dan guru yang disupervisi. Hal ini sejalan dengan penelitian Sharma. dkk (2011) yang mengungkapkan bahwa supervisi akademik haruslah bersifat kooperatif. Supervisi akademik harus melibatkan baik supervisor maupun tersupervisi. Hal ini berarti kepala sekolah selaku supervisor tidak hanya berperan pemimpin yang memberikan perintah pada stafnya namun juga sebagai penggerak staf untuk ikut aktif berpartisispasi dalam kegiatan disekolah khususnya supervisi akademik.

Jadwal pelaksanaan supervisi akademik di SMPN 1 Todanan Blora menggambarkan intensitas pelaksanaan supervisi akademik. Jadwal pelaksanaan supervisi disusun di awal semester baru yang bersifat melanjutkan jadwal yang telah di susun pada semester sebelumnya. Hal ini senada dengan penelitian Affero (2011) yang menyatakan bahwa pembentukan jadwal pertemuan antara mahasiswa dan pembimbing yang teratur, dapat membantu mahasiswa menyelesaikan pendidikan mereka oleh sebab itu supervisi diperlukan untuk mengawasi pelaksanaan jadwal yang telah tersusun. Hal ini berarti bahwa jadwal pelaksanaan suatu kegiatan menentukan hasil yang akan diperoleh dari pelakasaan kegiatan di suatu organisasi. Begitu pula supervisi akademik akan berjalan efektif dan efisien dengan mengikuti jadwal yang telah disusun diawal semester.

\section{Pelaksanaan supervisi akademik}

Pelaksanaan supervisi di SMPN 1 Todanan Blora secara keseluruhan dilakukan oleh kepala sekolah. Kepala sekolah senantiasa mengikuti aturan yang sudah ada dengan tujuan hakekat supervisi yang sebernarnya tetap terjaga. Kepala SMPN 1 Todanan Blora selalu menggunakan instrument penilaian berdasarkan pedoman supervisi dan menambahkan beberapa hal yang disesuaikan dengan kebutuhan guru untuk menyempurnakan instrument tersebut. Hal ini sejalan dengan penelitian Eslin (2012) yang menyatakan bahwa administrasi di sekolah dapat berjalan sesuai tujuan dan dapat memenuhi permintaan masyarakat yang terus berkembang apabila kepala sekolah melakukan perubahan dan inovasi yang disesuaikan dengan input dan output sekolah. Hal ini berarti kepala sekolah dalam melakukan supervisi perlu melakukan perubahan atau inovasi yang disusaikan dengan kondisi sekolah dan kebutuhan guru, namun hal tersebut harus tetap berlandaskan pedoman atau aturan yang sudah ditetapkan. Pelaksanaan suatu kegiatan di sekolah harus berdasarkan peraturan pemerintah dan strustur organisasi di sekolah bukan berdasarkan harapan dan keinginan semata.

Pelaksanaan setiap kegiatan disekolah haruslah tetap mendukung kegiatan lain. Supervisi kademik di SMPN 1 Todan Blora dilakukan dengan cara melakukan pengamat secara langsung bagaimana proses pembelajaran berlangsung. Kendati demikian pelaksanaan supervisi tidak mengganggu jalannya pembelajaran di kelas. Supervisi akademik di SMPN 1 Todanan Bloran mengikut prinsip terpadu bearti supervisi berjalan menyatu dengan program pendidikan. Hal ini senada dengan penelitian yang dilakukan oleh Dowie (2008) yang menyatakan bahwa supervisi bertujuan untuk menyeimbangkan hubungan atara pihak yang berhubungan dengan pendidikan mahasiswa Ph.D. (S3). Hal ini berarti pelaksanaan supervisi akademik dilaksanakan dengan memperhatikan hubungan antara kepala sekolah dengan guru dan guru dengan siswa. Supervisi akademik dijalankan dengan profesional untuk mendapatkan hasil 
yang maksimal tanpa mengorbankan kegiatan lain disekolah, termasuk proses pembelajaran di kelas.

Supervisi akademik di SMPN 1 Todanan Blora dilaksanakan dengan cara melakukan pengamatan kinerja guru selama proses pembelajaran di kelas. Pengamat tersebut bertujuan untuk mengidentifikasi keunggulan maupun kelemahan guru dalam proses pembelajaran. Keunggulan yang dimilki guru merupakan senjata untuk meningkatkan mutu pendidikan di sekolah, namun kelemahan guru dapat menghambat peningkatan mutu pendidikan di sekolah. Hal ini sejalan dengan penelitian yang dilakukan oleh Gurnam (2010) yang menyatakan bahwa kualitas siswa terlahir dari guru yang berkualitas, oleh sebab itu kepala sekolah harus memilki kemampuan dalam mengawasi pembelajaran dengan baik untuk menjaga kualitas pendidikan di sekolah. Hal tersebut berarti kepala sekolah selaku supervisor memilki peran penting dalam menjaga mutu pendidikan di sekolah. Seorang kepala sekolah harus memilki pengetahuan dan pemahaman yang baik mengenai pelaksanaan supervisi akademik.

Supervisi akademik di SMPN 1 Todanan Blora menggunakan teknik supervisi individual dengan cara observasi kelas. Supervisi akademik dapat memberikan kontribusi positif yang makasimal pada peningkatan mutu pendidikan apabila dilaksanakan dengan pemilihan teknik yang tepat. Pemilihan teknik yang tepat dapat membuat supervisi akademik berjalan efektif, efisien, dan tepat sasaran. Hal ini senada dengan penelitian yang dilakukan oleh Tshabalala (2013) yang menyatakan bahwa pencarian strategi supervisi instruksional merupakan kunci utama kesusksesan kegiatan supervisi instruksional. Hal ini berarti penetuan teknik atau strategi yang digunakan dalam pelakasanaan supervisi akademik merupakan hal yang sangat penting. Kepala sekolah harus mengadakan pengamatan untuk membandingkan tekniktenik supervisi lalu menentukan teknik supervisi mana yang paling tepat untuk diterapkan di sekolah.

Pelaksanaan supervisi akademik di SMPN 1 Todanan Blora memberikan dampak positif bagi peserta didik. Pelaksanaan supervisi akademik menjadikan peserta didik lebih aktif dan bersungguh-sungguh di kelas, sehingga hasil yang diperoleh siswa pun meningkat. Hal ini senada dengan penelitian Simon dan Charles (2011) yang menyatakan bahwa supervisi yang nyaman bagi guru dapat membantu guru meningkatkan kemampuannya dalam mengajar yang berdampak pada peningkatan hasil belajar siswa. Hal ini berarti supervisi memberikan kontribusi positif dalam peningkatan mutu pendidikan disekolah, dengan cara meningkatkan keprofesionalan guru dalam mengajar yang berdampak pada peningkatan hasil belajar siswa.

\section{Umpan balik Supervisi Akademik}

Komunikasi yang baik antara supervisor dan guru tersupervisi dapat membantu tercpainya tujuan supervisi akademik. Komunikasi antara supervisor dan tersupervisi berpusat pada pertemuan umpan balik. Pertemuan umpan balik di SMPN 1 Todanan Blora menunjukkan komunikasi yang baik antara kepala sekolah dan guru yang berfungsi untuk menemukan solusi atas kendala yang dialami guru. Hal ini senada dengan penelitian Badah (2013) yang mnyatakan bahwa untuk mengatasi kesulitan yang dihadapi pengawasan pendidikan di sekolah-sekolah perlu adanya komunikasi dan pertukaran pengalaman dan informasi sebagai umpan balik. Berarti penciptaan suasana yang nyaman dan hangat dalam pertemuan 
umpan balik diperlukan untuk menghasilkan komunikasi yang baik anatar supervisor dan guru tersupervisi. Komunikasi yang baik dapat membuat kedua pihak lebih terbuka dan mudah untuk menemukan solusi bersama untuk mengatasi kendala yang dialami guru dalam pembelajaran.

Pertemuan umpan balik di SMPN 1 Todanan Blora berisi diskusi antara kepala sekolah dengan guru yang disupervisi mengenai hasil pengamatan yang telah dilakukan kepala sekolah terhadap kinerja guru. Kepala sekolah mengidentifikasi keunggulan dan kelemahan guru sebelum pertemuan dimuai dan menyampaikan hasilnya pada guru ketika pertemuan umpan balik dimulai. Hal ini senada dengan penelitian yang dilakukan oleh Louise, dkk (2013) menyatakan bahwa model supervisi yang digunakan memiliki kekurangan yang banyak ditemukan terkait tingkat pendidikan, waktu untuk supervisi, dll. Kekurangan yang ditemukan dianggap sebagai alat yang berharga untuk memperbaiki dan meningkatkan kualitas pendidikan keperawatan. Hal ini berarti penyampaian hasil supervisi atau observasi kelas sangat penting dilakukan untuk memperbaiki kekurangan yang ditemukan dalam proses supervisi akademik. Kepala sekolah bersama guru berusaha mencari solusi untuk mengatasi kendala yang dihadapi guru sebagai upaya peningkatan kualitas pendidikan di SMPN 1 Todanan Blora.

Guru di SMPN 1 Todanan Blora menjadikan pertemuan umpan balik supervisi akademik sebagai wahana untuk pencerminan diri. Dalam pertemuan umpan balik, guru dapat mengetahui kelebihan maupun kekurangannya. Hal ini senada dengan penelitian yang dilakukan oleh Borch (2012) yang menyatakan bahwa secara keseluruhan dosen pembimbing di empat universitas keperawatan merasa sudah melakukan yang terbaik untuk pendidikan, namun setelah adanya supervisi, mereka menyadari kekurangan pada diri mereka sendiri yang dapat digunkan untuk meningkatkan kualitas mereka. Hal ini berarti pertemuan umpan balik setelah pelaksanaan supervisi merupakan hal yang sangat penting dimana guru dapat mengetahui kelemahan yang selama ini tidak guru sadari. Hal ini berimplikasi pada guru dapat memperoleh dorongan moral atau semangat untuk terus memperbaiki diri.

\section{Tindak Lanjut Supervisi Akademik}

Supervisi akdemik merupakan kegiatan yang bersifat kontinyu. Supervisi akademik di SMPN 1 Todanan Blora dilakukan secara berkelanjutan dan berkesinambungan, hal ini ditunjukkan dengan dilakukannya tindak lanjut atau pengawas terhadap kinerja guru setelah supervisi akademik berlangsung. Hal ini sejalan dengan penelitian yang dilaukan oleh Ogbonnaya, dkk (2013) yang menyatakan bahwa kegiatan pendididkan disekolah perlu adanya pemeriksaaan dan pengawasan untuk mencapai tujuan pendidikan tersebut. Hal ini berarti bahwa pengawasan terhadap dampak atau kontribusi supervisi akademik secara keseluruhan perlu dilakukan untuk memastikan peningkatan kinerja guru. Pengawasan secara teratur yang dilakukan oleh kepala sekolah akan mendorong guru bekerja lebih baik dan disiplin.

Tindak lanjut supervisi akademik di SMPN 1 Todanan Blora dilanjutkan dengan pemberian fasilitas penunjang kemampuan guru. Kepala sekolah memberikan kesempatan pada guru untuk mengikuti pelatihan dan kegiatan Musyawarah Guru Mata Pelajaran (MGMP) dengan tujuan guru memperoleh pengalaman baru yang mendukung peningkatan kemampuan guru dalam mengajar. Hal ini senada dengan penelitian yang dilakukan oleh 
Nordentoft, dkk (2011) yang menyatakan bahwa mahasiswa yang memilki kemampuan interaksi yang baik menunjukkan produktifitas yang baik dalam bidang akademik. Dalam kasus tersebut supervisor berperan penting untuk memberikan pelatihan pada mahasiswa yang mengalami kesulitan dalam berinteraksi. Hal tersebut berarti upaya meninjak lajuti hasil supervisi merupakan hal yang diperlukan untuk memperoleh kontribusi positif dari supervisi akademik. Kepala sekolah selaku administrator di sekolah perlu memberikan fasilitas yang mendukung guru untuk meningkatkan kemampuan dalam mengajar..

\section{PENUTUP}

Perencanaan supervisi akademik di sekolah dilaksanakan dengan cara penyusunan jadwal pelaksanaan supervisi kademik dan persiapan instrument penilaian supervisi akademik. Perencanaan supervisi akademik dilakukan dengan cara diskusi yang melibatkan kepala sekolah selaku supervisor tunggal dan wakil kepala sekolah bagian kurikulum. Penyusunan jadwal pelaksanaan tidak melibatkan guru dengan tujuan pembagian waktu supervisi dapat dilakukan secara merata dan adil.

Pelaksanaan supervisi akademik di SMPN 1 Todanan Blora dilaksanakan di setiap semester sesuai dengan jadwal yang sudah disusun yang dimulai dengan melakukan pertemuan awal antara supervisor dan guru tersupervisi kemudian dilajutkan dengan pelaksanaan observasi kelas oleh supervisor. Supervisor memberikan penilaian terhadap guru yang disupervisi berdasarkan instrumnent penilaian yang telah dipersiapkan.

Umpan balik supervisi akademik di SMPN 1 Todanan Blora dilaksankan dengan cara diskusi atara supervisor dan guru tersupervisi setelah pelaksanaan observasi kelas. Supervisor dan guru yang disupervisi mereview jalannya supervisi akademik dan membahas hasil supervisi akademik. Supervisor dan guru tersupervisi berdiskusi untuk menemukan cara dalam upaya peningkatkan kinerja guru.

Tindak lanjut supervisi akademik di SMPN 1 Todanan Blora dilakukan untuk memantau dan mengawasi perubahan guru berkenaan dengan kegiatan supervisi akademik yang telah diperoleh guru. Kepala sekolah melakukan pengawasan pada guru setiap hari dengan berkeliling dan memantau kegiatan pembelajaran dari jendela ruang kelas yang bertujuan untuk meningkatkan kedisiplinan guru dan memotivasi guru untuk dapat mengembangkan diri.

\section{DAFTAR PUSTAKA}

Affero, Ismail. 2011. Improving the Development of Postgraduates' Research and Supervision. Journal of International Education Studies, Vol. 4, No. 1, Febuari 2011

Carrie Ann Stephens 2009 The Process of Supervision with Student Teachers Choice a Quality Study. Journal of Agricultural Education 89 Volume 50, Number 3, 2009

Dowie I. 2008. Reflection On Academic Supervision. Art \& Science Nursing Standard Journal. Vol 23. No 11. November 2008

Engin, Aslanargun. 2011. Principals' leadership in school administration: A study of principal effectiveness in Turkish public schools. African Journal of Business Management .Vol. 6(36), pp. 9914-9922. September, 2012

Gurnam Kaur Sidhu. 2010. Formative Supervision of Teaching and Learning: Issues and 
Concerns for the School Head master. European Journal of Scientific Research. ISSN 1450-216X Vol.39 No.4 (2010), pp.589-605

Louise, Marrie. 2013. A clinical supervision model in bachelor nursing education Purpose,content and evaluation. Nurse in Practice Journal. Vol 13, pp: 506-511. Februari 2013

Muslim, Sri Banun. 2009. Supervisi Pendidikan Meningkatkan Kualitas Profesionalisme Guru. Bandung: Alfabeta

Ogbonnaya, Umemetu; Obiweluozor, Nkechi; Momoh, , N O. 2013. Supervision And Inspection For Effective Primary Education In Nigeria: Strategies For Improvement. Academic Research International Journal. Vol. 4.No. 9. Juli 2013

Olivia, Peter F. 1984. Supervion for Today's School. New York: Longman.Inc

Peraturan Menteri Pendidikan Nasional (PERMENDIKNAS) No. 16 Tahun 2007 tentang Standar Kualifikasi Akademik dan Kompetensi Guru

Prasojo, Lantip Diat dan Sudiyono. 2011. Supervisi Pendidikan. Yogyakarta: Gaya Media.

Sharma, Sailesh; Yusoff, Marohaini; dan Kannan, Sathiamoorthy. 2012. "Instructional Supervision in Three Asian Countries-What Do Teachers \& Principals Say?". Journal of Education and Management Technology. Vol.13 No 4. Pg: 34-38.

Simon dan Charles. 2011. 'We teach plastic lessons to please them': The influence of supervision on the practice of English language student teachers in Kenya. Language Teaching Research Journal Permission. Vol 15. No 4. 2011

Sukmadinata, Nana Syaodih. 2009. Metode Penelitian Pendidikan. Bandung: Remaja Rosdakarya.

Sutama. 2012. Metode Penelitian Kuantitatif, Kualitatif, PTK, R\&D. Kartasura: Fairuz Media. . 2014. Penelitian Tindakan PTK, PTS, dan PTBK. Kartasura: Fairuz Media

Mapolisa, Tichaona Thembinkosi Tshabalala, (2013), Instructional Supervisory Practices of Zimbabwean School Heads. Greener Journal of Educational Research ISSN: 22767789 Vol. 3 (7), pp.354-362, September 2013.

Nordentof, Helle Merete, dkk., (2013), Collective Academic Supervision: A Model For Participantion And Learning In Higher Education, Springer Science+Business Media B.V. 2012: 581-593, October 2012

Turmuzi. 2011. Meningkatkan Kualitas Pembelajaran Melalui Kegiatan Supervisi. www. kompasiana.com. Diakses pada hari Senin 30 November 2015.

Undang-Undang Dasar tahun 1945 alenia IV

Winaryanti, Eny. 2014. Evaluasi Supervisi Pembelajaran. Yogyakarta: Graha Ilmu 